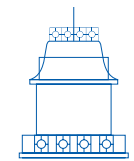

ARTÍCULOS

DE REFLEXIÓN

\title{
The posters of May '68 and their significance for a contemporary critique of capitalism
}

\author{
Jones Irwin \\ Dublin City University, Dublin, Ireland \\ E-mail: jones.irwin@dcu.ie
}

Recibido: 24 de enero de 2020 | Aprobado: 22 de mayo de 2020

https://doi.org/10.17533/udea.ef.n62a10

\begin{abstract}
This essay explores the original political significance of the posters of May'68 as a critique of capitalism, as well as extending this approach to a critique of contemporary capitalism in 2020. The slogans of '68 are deceptively simple and we look to the importance of the political ideas expressed aesthetically as having immediate impact in the late 1960s, but also the underlying Situationist philosophy which influenced them. We also explore the contemporary significance of Situationist theory, especially in the context of the renewal of Marxist thought in the $21^{\text {st }}$ century. This renewed Leftist critique of capitalism emerges as articulated through newer social and political movements of the current times, particularly through the political philosophy of Slavoj Žižek and his auto-critique of the former Yugoslavia.
\end{abstract}

Keywords: May '68 Posters, Marxism, Situationism, Debord, $21^{\text {st }}$ Century, Žižek

Cómo citar este artículo:

Irwin, J. (2020). The Posters of May '68 and Their Significance for a Contemporary Critique of Capitalism. Estudios de Filosofía, 62, 175-188. https://doi.org/10.17533/udea.ef.n62a10 


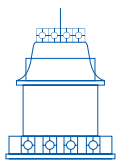

ARTÍCULOS

DE REFLEXIÓN

\section{Los carteles de mayo del 68 y su significación para una crítica contemporánea del capitalismo}

Resumen: Este ensayo explora el significado político original de los carteles de mayo del 68 como una crítica del capitalismo, y también extiende este enfoque a una crítica del capitalismo contemporáneo en 2020. Los lemas del 68 son engañosamente simples; en este texto se muestra la importancia de las ideas políticas expresadas estéticamente y la manera en que tuvieron un impacto inmediato a fines de la década de 1960, pero también la filosofía situacionista subyacente que las influyó. También exploramos el significado contemporáneo de la teoría situacionista, especialmente en el contexto de la renovación del pensamiento marxista en el siglo XXI. Esta renovada crítica izquierdista del capitalismo surge articulada a través de los nuevos movimientos sociales y políticos de la actualidad, particularmente a través de la filosofía política de Slavoj Žižek y su autocrítica de la ex Yugoslavia.

Palabras clave: Carteles del 68, marxismo, situacionismo, Debord, siglo XXI, Žižek

\section{Jones Irwin}

Associate Professor in Philosophy and Education at the Institute of Education, Dublin City University, Republic of Ireland. Between 2014-2019, he was seconded as Project Officer on the first state curriculum in values and multi-beliefs in Ireland. He has published widely in philosophy of education and ethics, for example his monograph on Freire entitled Paulo Freire's Philosophy of Education: Origins, Development, Impact and Legacies (Bloomsbury, London 2012). He has a longstanding interest in South and Latin American educational philosophy. He is currently completing a monograph on existential thought, entitled The Pursuit of Existentialism (Routledge, forthcoming 2020). 


\section{Introduction}

The political posters of the Atelier Populaire or "People's Workshop", associated with the May '68 uprising in Paris, continue to speak to and provoke us today. In their original underground production, bringing students artists and factory workers together, they sought to represent in the most direct fashion possible what the revolutionary struggle about late capitalism meant and tried to achieve as an alternative. This was no cerebral Marxism divorced from everyday life (a fate which sadly befalls Althusser's Marxism [Althusser, 1994] at this time) but rather an eclectic and somewhat heterodox social movement where these posters became symbols of the everyday struggle. At the same time, these posters came to be plastered on walls in the very streets and factories where the struggle was taking place. As the original statement from the Atelier Populaire has it: "To the reader -the posters are weapons in the service of the struggle and are an inseparable part of it; their rightful place is in the centres of conflict, that is to say in the streets and on the walls of the factories" (Vermès \& Kugelberg, 2011, p. i).

The second part of this statement captures our own contemporary interest in this problematic. These posters were never intended as a once off movement: "This is why this book should not be taken as the final outcome of an experience but as an inducement for finding through contact with the masses new levels of action and depth on the cultural and on the political plane" (Vermès \& Kugelberg, 2011, p. ii). One of the May '68 posters infamously asks the searching question "Et Après?" ("what afterwards?"), foregrounding what Kristin Ross has referred to as the "afterlives of '68" (Ross, 2002). This "long '68" will undoubtedly continue to surprise us with its new mutations and metamorphoses. What significance can we thus find in the posters and their statements and meaning for the contemporary struggle against and critique of capitalism? Here, we will also look to affinities with specific aspects of the more contemporary Left, with particular reference to Slavoj Žižek and the Ljubljana school of cultural and political analysis (Irwin \& Motoh, 2014).

\section{Context for the ' 68 posters and their meaning}

1967 was the year that Guy Debord published his infamous text Society of the Spectacle (Debord, 2000). This wasn't exactly the beginning of the Situationist philosophy. Rather, the latter had emerged in disorderly fashion some ten years earlier in a remote north Italian tavern. This decadent origin put Marxism together with the aesthetic movement of Symbolism, joining politics and poetry to make a more hybrid revolution. As Henri Lefebvre had it, "Marx said 'Change the world', Rimbaud said 'Change life'; for us, these two watchwords are one" (Lefebvre, 2002, p. 3). This wouldn't be the last time this vision would relocate from France to Italy and back again. Gianfranco Sanguinetti's "The Real Report on the Last Chance to Save Capitalism", an incendiary satire on Italian politics 
(influenced by Machiavelli) would see him deported from an unstable and Red Brigade Italy in the 1970s -to where? To France, of course!

Should we still be reading Guy Debord in 2020 or encouraging others to read him politically for the first time in a contemporary context? Our answer is a resounding yes! In the context of increasing economic inequality and social alienation, there are specific lessons which Debord's philosophy of Situationism can teach us which can move our discussions onwards and upwards (Debord, 2000). Community-building, collective political action and workers' unions are more vital than ever but how do we relate these spaces of transformation to the structures of money, time, and power which alter our daily lives? More recently, the emergence of the Covid 19 global health crisis has again demonstrated the need for a reevaluation of community and co-operation, as against narrow economism and globalisation. Debord and his comrades give us some polemical answers to our perennial dilemmas and some ongoing questions they could never resolve in their own turbulent lifetimes. These recalcitrant problems, the edgy crises of late capitalist economy and society, would take their toll. Debord's personal labour for the Leftist dialectic would end in tragic suicide. If nothing else, it shows we can be sure he meant it. Situationism was no dilettantism (contra the suppositions of today's Sunday supplements). Sometimes unresolved dilemmas from previous radical thinkers and thought-systems are the most fruitful sources to mine for new ideas to address our current predicament.

One of the most pressing problems for Debord is whether the age old Marxist distinction between "truth" and "ideology" is any longer pertinent in late capitalistic, society of the spectacle. His proposed answer to this is typically ambiguous in sidestepping the direct question and relocating the problem to the plane of what he refers to as emergent revolutionary "situations". These enigmatic and surprising situations (which give the name to the concept and counter-cultural movement of Situationism per se) succeed in subverting the impasse in the more mainstream discussions on the Left of the science/ideology distinction. In this, Debord has also something to say to the current obsession with whether we are in a "post-truth" era. The example of the late 1960s shows that this is hardly a new question and also that the problematic of "post-truth" is not monopolised by Right wing politics. Rather the question of "post-truth" has a venerable Leftist tradition and history too, however problematic and uneasy this might be for more orthodox interpretations. Facing up to this fact might allow us better resources to properly understand and critique the emergence of the Alt-Right rather than simply hiding behind platitudinous and reductively dismissive accounts.

If in sidestepping the epistemology question (by claiming a "post-truth" situation), Debord succeeds in a certain intra-Leftist coup, it is still the case that the proposed new concept of the "situation" brings its own vulnerabilities to the cause. These new "situations", we are told, are fragile and can become "recuperated" and "commodified" back into the oppressive system of dominant political power (Debord, 1990, 3ff.). Or to 
translate -beware of conceit, bad faith and the betrayal machine (especially amongst so-called colleagues or comrades). As well as being a true revolutionary, Debord was a true paranoiac. In many respects, this fundamental ambiguity of Debord's approach, affirming a communist society whilst decrying orthodox Leftism and advocating subjective freedoms, can be seen as expressly mirrored in the May '68 slogans. For example, a '68 slogan with communist intent such as "Only the one exists" ("Seul l'un existe" 144 [Vermès \& Kugelberg, 2011, p. 144]) can be juxtaposed with a far more libertarian and erotic dictum such as "I come in the paving stones" "Je jouis dans les pavés" [Vermès \& Kugelberg, 2011, p. 105]). This affirmation of contradictoriness can be traced therefore both through Debord's own evolution of Situationism and in the organic movement of '68 itself. We will see later how this contradictoriness is maintained in specific versions of contemporary Leftism in their critique of capitalism.

\section{Debord's development of Situationism}

truth is considered profane and only illusion is sacred; sacredness is in fact held to be enhanced in proportion as truth decreases and illusion increases so that the highest degree of illusion comes to be the highest degree of sacredness (quoted Debord, 1967, p. 6).

There is a thus difficult paradox at the heart of Situationism. On the one side, we must maintain the Marxist critique of ideology all the more in the "Society of the spectacle", in the contemporary spectacular epoch of postmodernity. Thus we find (quoted above) as a paradigmatic epigram to Debord's text the Feuerbachian distinction between truth and illusion, the sacred and the profane. But alongside this critique we must maintain a simultaneous (and all the more vigorous) suspicion of our very criticality, an auto-Leftist critique. We must be vigilant against ourselves and our worst tendencies to complacency and revolutionary hubris.

One is reminded of the vehement critique of paternalism in Paulo Freire's work and writings, which he often directs against himself (a sign of rare authenticity) (Freire, 1992; Freire, 1996). It is an antidote for Freire against the pseudo-revolutionaries and the pseudo-philosophers whose empty words and actions push the effort for real change and transformation in society back each time they open their pontificating mouths. The universities are full of such people. Freire quotes a letter:

an excellent letter from a group of workers in São Paulo; "Paul" they said, "keep writing -but next time lay it on a little thicker when you come to those scholarly types that come to visit as if they had revolutionary truth by the tail. You know, the ones that come looking for us to teach us that we're oppressed and exploited and to tell us what to do" (Freire, 1992, p. 63). 
Jacques Rancière declares a similar insight when he says that his books from the 70s (written in the crucible of acute guilt and recrimination attendant on the '68 failures) declare war on the theory of the inequality of intelligences at the heart of supposed critiques of domination. Instead, we are to hold that all revolutionary thought must be founded on the inverse presupposition, that of the capacity of the dominated (Rancière, 2010b, p. iv). This is a powerful reminder of the need for socalled liberatory thought and philosophy to apply its critical lenses also to its own assumptions and practices.

This "capacity of the dominated" is, of course, hard to decipher or recognise in a climate which seems everywhere dictated by Debord's Spectacle. Debord even distinguished between three distinct and ever more fatalistic forms of the spectacular society, from the concentrated spectacle which functions through cult of personality, through second, dictatorship and totalitarianism which functions through brute and crude force (Germany/Russia) finally through third, to the diffuse spectacle which was more implicit or subterranean if all the more effective for it (USA) (Debord, 2000, p. 32). These days the USA or the UK adopts more the first posture. The second was more associated with, for example, the nondemocratic communism of Stalin. What Debord called the integrated spectacle combined the two (in the late 1960s, this was Italy and France). Freire's work gives a diagnosis of how these social and political pathologies are expressed in a Latin American context (Freire, 1996), with his strong diatribe against neo-colonialism in, for example, Brazilian politics and education. Freire also connects this critique to the wider Latin American context in his deconstruction of development education approaches to literacy education rooted in a "false charity" (Freire, 1996). As Thesis 42 has it, "The Spectacle is the stage at which the commodity has succeeded in totally colonising social life" (Debord, 1990, p. 24). In 2020, immersed in a revival of Alt-Right politics and power, as well as the media, but still all-too-real, frenzy of the Covid-19 virus, we might say that Debord's integrated spectacle has become near universalist.

So far so systematic. But we should also remember that any such vision of an overarching or even coherent systematicity to Situationism is misleading. Their programme was epigrammatic not systematic, bequeathing only scraps and preliminary ideas, vague hypotheses and blurry vignettes. No completed or coherent body of work endures. This is also the joy of Debord, the anarchist slant of his vision. With Debord and Situationism, the old Leftist disagreement between Marx and Bakunin endures, and takes on new aspects in the contemporary world (Mc Lellan, 1980). But here we also see the congruence between specific versions of neo-Marxism and possibilities within anarchist politics and praxis. The posters of ' 68 and their implicit Situationist philosophy emerge in this dual space of ideology. 


\section{Posters and graffiti of May '68}

Despite the relentless self-critique (even self-derision) of the Situationists, many of Debord's phrases and statements became part of the Posters and Graffiti of the May '68 events and emergent social movements. In the figure below, however humorous or satirical, we see a reinforcement of the critique of ideology. On Vous Intoxique -You Are Being Poisoned! (Vermès \& Kugelberg, 2011, p. 5). This is the continuity with the Marxist tradition, the media spectacle of the '60s world being interpreted through the prism of ideology critique. You are being duped by television, radio, consumerism, capitalism. The overt critique of capitalism is shared by the Marxist and anarchistSituationist perspectives.

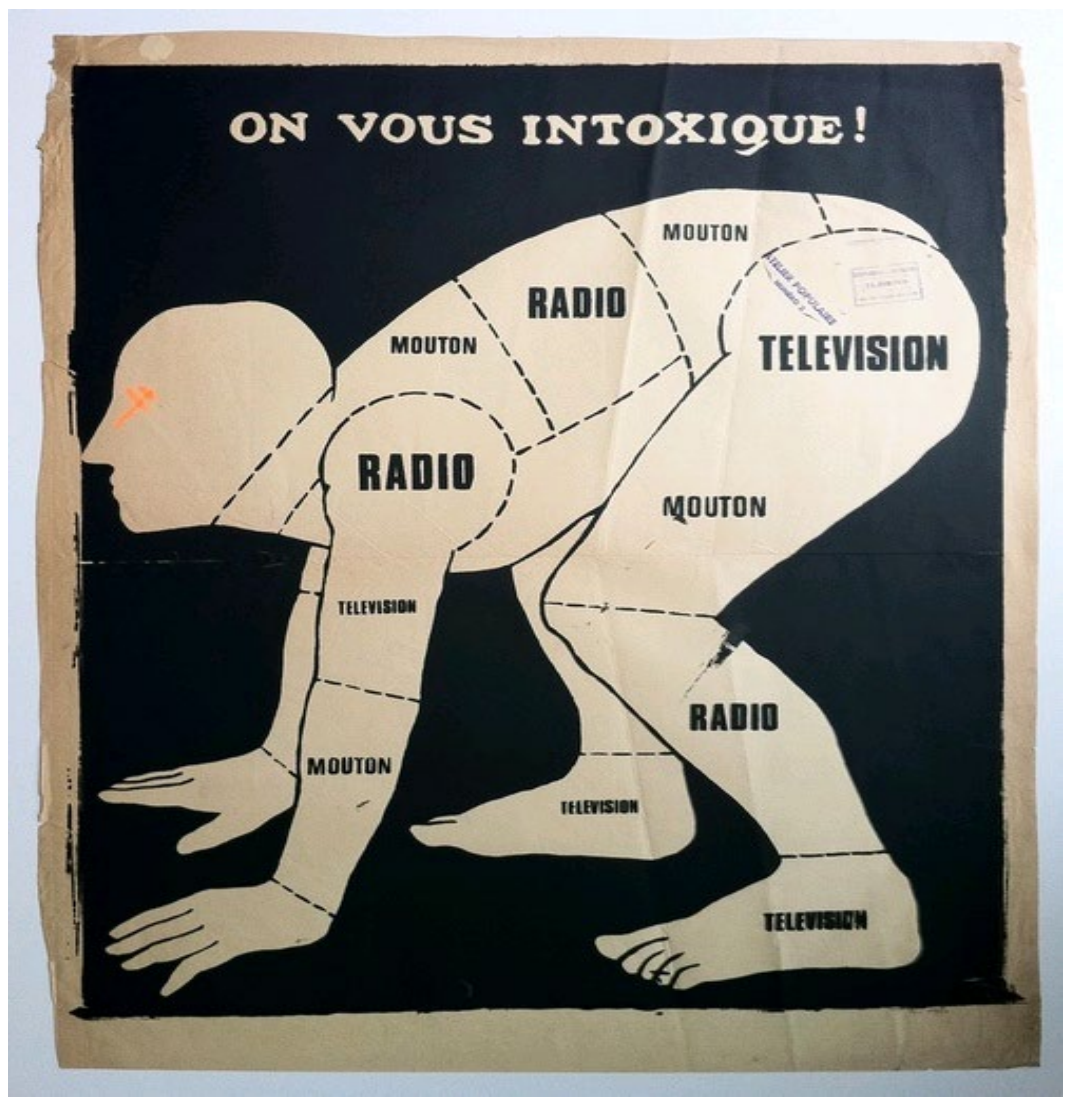

Figure 1

On Vous Intoxique!

Reprinted from Vermès \& Kugelberg (2011, p. 5) 
But the avowal of a critique of ideology also comes with a significant philosophical health warning from the Situationists and this is a self-satire that is also prominent in '68 and again visible in the posters. "Participation - All the Better to Eat You With My Children!" (Vermès \& Kugelberg, 2011, p. 6). How the dream of emancipation and the empowerment of the underclass (or "the children" here as another example of infantilism) runs aground! Perhaps all this talk of increasing radicalisation and democratisation ("we are so much more radical than you are") is just another ruse to co-opt any potentially transformative action into complicity with the forces of power. This poster and this declaration also contains an angry and somewhat disillusioned question; what then would authentic participation in the revolution be, what would it look like? What could it possibly feel like in the real world beyond the spectacle? Is there even such a place?

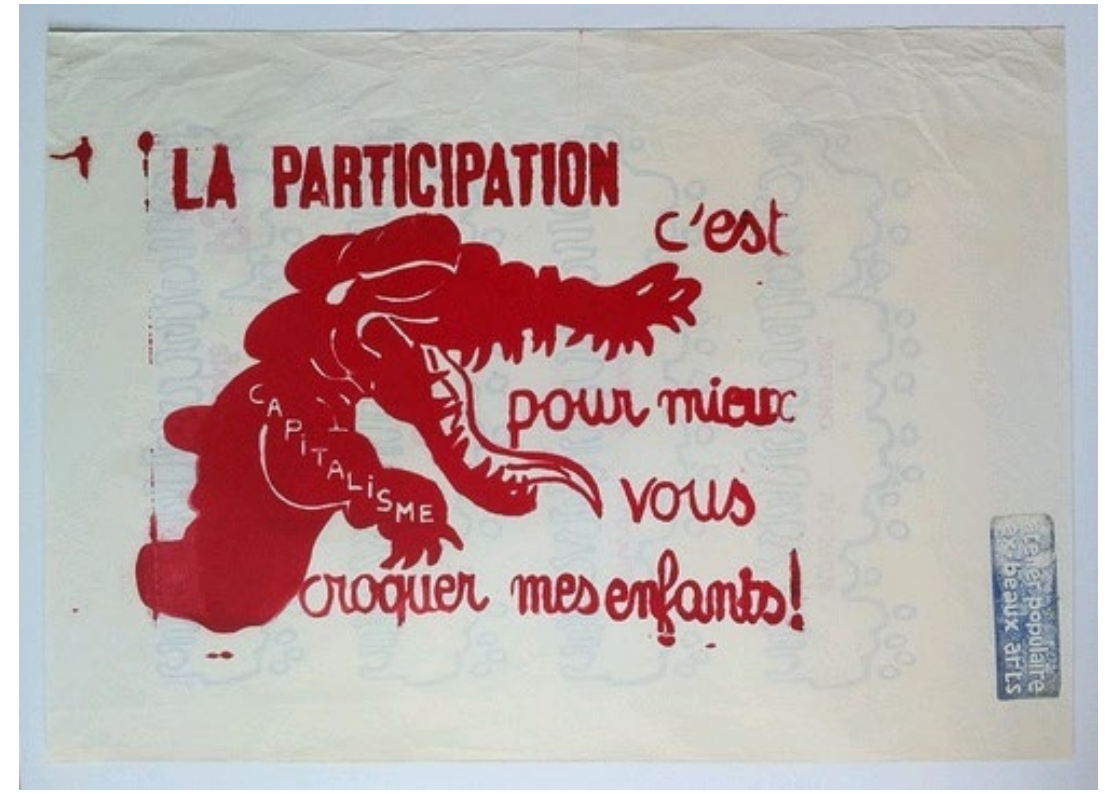

Figure 2

Participation - All the Better to Eat You With My Children!

Reprinted from Vermès \& Kugelberg $(2011$, p. 6)

The final poster and slogan we will look at here takes the discussion on one stage further. "Return to Normal" -the failure of participation leads to the failure of the revolution leads to the reinforcement of the status quo. What's worse -without the revolution, there would be no return to normal. It is precisely the pseudo-revolution that acts as a condition of possibility for the reinforcement and maintenance of power in the longer-term, primarily as it allows a certain "illusion" of change to keep the previously restless population happy. We go back from figure 3 to figure 1. On Vous Intoxique. The 
Revolution is the Ideology; May '68 itself becomes the propaganda. This is also then the vicious circle of Debord's analysis and the overriding lesson of Situationism. The Spectacle is Everywhere! As Debord states in Thesis 42 -"The Spectacle is the stage at which the commodity has succeeded in totally colonising social life" (Debord, 1990, p. 24). The fatal danger for Leftism in a critique of contemporary capitalism is thus that it becomes merely part of the problem, while obscuring the potential political and social resolution.

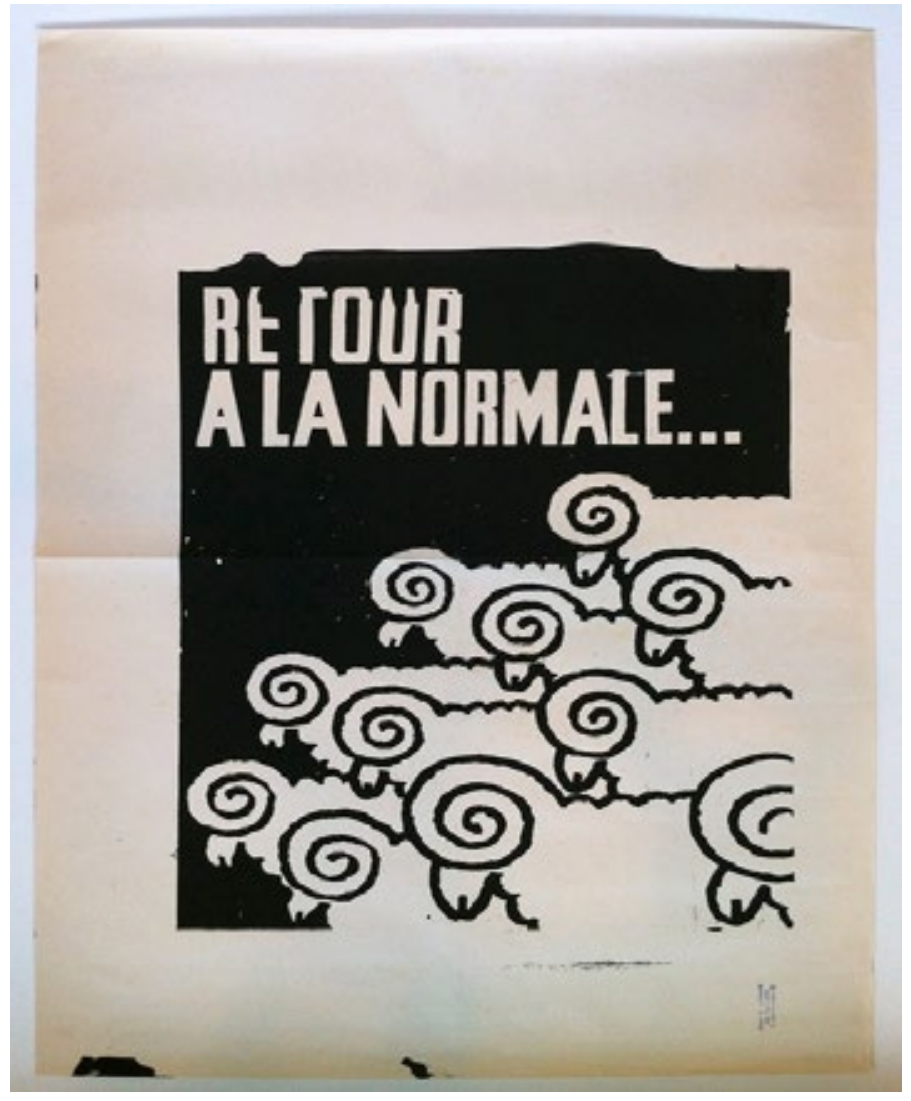

Figure 3

Return to Normal

Reprinted from Vermès \& Kugelberg (2011, p. 25)

\section{Whither goes the Situationist in the contemporary spectacle?}

But all is not lost. The '68 posters also warn us to be wary of the all-seeing panoptical hermeneutics of philosophy. This wariness of philosophy as a discipline as such (being connected to bourgeois power) has a long history on the Left. As Marx states in Thesis 
11 of his Theses on Feuerbach) "Philosophers have hitherto only interpreted the world in various ways; the point is to change it" (Marx, 1992a, p. 56). In a related key, Antonio Gramsci tells us that

Philosophy in general does not in fact exist. Various philosophies or conceptions of the world exist, and one always makes a choice between them. How is this choice made? Is it merely an intellectual event, or is it something more complex? And is it not frequently the case that there is a contradiction between one's intellectual choice and one's mode of conduct? (Gramsci, 1986, p. 19).

The lesson is clear -enough with cognitivism and brain work and hermeneutics! It is time for practice, what Lacan called the passage to act (Žižek, 2006). As commentators have noted, we can say surely that the text The Society of the Spectacle endures as Debord's masterpiece, more broadly as the meisterwerk of the eclectic Situationist movement. It is a brilliant prose poem and Debord saw it as an act of demystification, an exposé of our everyday hypocrisy, including the hypocrisy of the radical Left (which Debord was the most bitter and unforgiving about). He was enough of an avant-gardist to be able to call out this hypocrisy -without fear.

But where to now? Perhaps the closest philosophical and social movement to Situationism in more recent times has been the movement of NonDogmatic Marxism in the Former Yugoslavia, associated especially with the Zagreb Praxis group (Irwin \& Motoh, 2014; Žižek, 1989). They began optimistically with the early Marx, with the humanist vision. This would eventually morph into the social and political work of Slavoj Žižek and the Ljubljana School, a form of dissident thinking on the Left that has had such a significant if iconoclastic impact on European philosophy, well beyond Slovenia (Irwin \& Motoh, 2014; Žižek, 1994a). This latter version of ideology-critique is certainly less optimistic as well as less humanistic, but one can argue that it is thus all the more resourceful in the contemporary age for these two disavowals of philosophical crutches. Did Diogenes of Sinope teach us nothing? - perhaps they were listening more intently in the former Yugoslavia. Who would have thought that an esoteric hybrid of Marxism and Lacanianism (what some call "erratic Marxism") could have become so influential on the Leftist reformist movement which called for an end to the bureaucracy and corruption of state socialism in the former Yugoslavia? Moreover, it has also spawned an influential and significant aesthetic wing of artists and musicians, for example the idiosyncratic and satirical nationalism of Laibach (Irwin \& Motoh, 2014). What marks out Žižek's work and the relation to the Former Yugoslavia is the way in which the internal dialogue of Marxism evolves in a very particular way in the latter context, with an allegiance emerging between Marx, Lacan and a radical form of psychoanalysis. The socio-political importance of this theory and praxis can be traced clearly in the Slovenian situation (Irwin \& Motoh, 2014). It will also emerge as a distinctive vision of the relation between education, society and politics. 
In his preface to Žižek's The Sublime Object of Ideology, the Argentine Marxist Ernesto Laclau outlines one of the most "original features" of the "Slovenian Lacanian school" as is its "insistent reference to the ideological-political field" as well as its outline of "the main characteristics of radical democratic struggles in Eastern European societies" (Laclau, 1989, p. x). One instructive concept in this context is the concept of "ideology", a notion which has been central to the Marxist tradition of critique. Žižek's work shows tensions in its elaboration of the notions of "ideology" and "critique of ideology". Already in 1989, Žižek was signalling an important move away from the "false consciousness" notion of ideology:

ideology is not simply false consciousness as an illusory representation of reality, it is rather this reality itself which is already to be conceived of as ideological; ideology is a social reality whose very existence implies the nonknowledge of its participants as to its sense (Žižek, 1989, p. 21).

In his introduction to his edited volume Mapping Ideology (Žižek, 1994a), entitled "The Spectre of Ideology" (Žižek, 1994b), Žižek continues to argue for the "pertinence" of the notion of ideology: "we are within ideological space proper the moment (whether true or false) a content is functional with regard to some relation of social domination ("power", "exploitation") in an inherently nontransparent way" (Žižek, 1994b). In successive versions of Enjoy Your Symptom: Jacques Lacan in Hollywood and Out (Žižek, 1992), Žižek relates the concept of "ideology" to Lacanian (and Marxist) notions such as "fetish" and "symptom" itself. In a Preface to the 2008 edition (Žižek, 2008), entitled "Enjoy your Symptom - or Your Fetish?", Žižek generates a certain ambiguity here between the original concept of "symptom" and the newer concept of "fetish". Can one concept replace the other in the Žižekian analysis? The related notion of "sinthome" also comes to have significance in the later Lacan's work and in Žižek's own analysis (Žižek, 2008), complicating matters further.

What is at stake in these theoretical manoeuvres? If the earlier conception of "ideology" (and in the Marxist tradition, "false consciousness") seemed to elaborate a (utopian) resolution to the contradictions of contemporary society, politics and education, the later conceptions point rather to a notion of ideology where a certain "deadlock" must be borne, both at the level of subject and at the societal level. For example, the conception of "fetish" is described as follows in its difference from the "symptom", this from the 2008 preface: "Fetish is effectively the reversal of the symptom; that is to say, symptom is the exception which disturbs the surface of the false appearance; the point at which the repressed other scene erupts. While fetish is the embodiment of the lie which enables us to sustain the unbearable truth" (Žižek, 2008, p. ix). For a real empirical reference point in this context, we might refer to the whitewashing by Tito's state socialism of conflict, pointing to a far more messy, complex ideological reality under Yugoslav socialism. 
Although each of these successive notions can be seen as Lacanian (and indeed Freudian), there is also a strong connection back to the Marxist understanding of these concepts (as Žižek notes in The Sublime Object of Ideology, "How Marx Invented the Symptom" [Žižek, 1989]). But the Marxism presented here is crucially of the "nondogmatic" perspective, wary and even hostile to a more (utopian) resolution to the contradictions of contemporary society (Žižek, 2008). Instead, for Žižek, the theoretical matrix of Marx-Lacan rather points away from utopianism to a fundamental "failure", something which he identifies particularly with Lacan's Seminar XX: "Seminar XX [Encore] stands for his ultimate achievement and deadlock; (...) in the years after, he desperately concocted different ways out [the sinthome, knots etc] all of which failed; so where do we stand now?" (Žižek, 2012a, p. 18).

Thus to follow Žižek's question, "so where do we stand now?", we might ask whither the critique of capitalism today in 2020, if we are to take it in a Žižekian Leftist direction? Once more, we might reiterate: let us move away from a (utopian and all-too-easy) resolution to the contradictions of contemporary society, politics and education. Rather, in society as in the educational sphere, a Žižekian and (Lacanian) psychoanalytical critique of ideology is one where a certain "deadlock" must be borne, both at the level of subject and at the societal level. As against the over-simplicity of the diagnostics of the symptom, we should rather foreground the diagnostics of the "fetish":

Fetish is effectively the reversal of the symptom; that is to say, symptom is the exception which disturbs the surface of the false appearance; the point at which the repressed other scene erupts. While fetish is the embodiment of the lie which enables us to sustain the unbearable truth (Žižek, 2008, p. ix).

This emphasis on the recalcitrance of ideology and a certain irreducibility of alienation, both societal and pedagogical, would be at least one of the lessons we might take from Žižek's recent work and the wider discourse of the Ljubljana School of Psychoanalysis.

These experiments with ideology, politics and truth can be risky. They display a disregard for convention and orthodoxy and in their interrogation of phenomena such as fascism, they can run into the accusation of complicity with the Rightist ideology (insofar as they refuse easy solutions and adopt provocative stances). This is also a scene of reading where their satires of identification (with Yugoslav or Slovene nationalism for example) can be interpreted literally. But this is a risk that must be run, whether aesthetically or politically. This is a revolutionary risk. It is precisely in this spirit that the heterodox amalgam of Marx and Lacan emerges in Slovenia in the first place in the '80s (Žižek, 1989). It is also the same spirit that influences Jacques Rancière to turn away from the top-down science/ideology distinction in the somewhat deterministic Marxism of his mentor Althusser, for a far more risky embrace in a post-'68 context of the "capacity of the dominated" (Althusser, 1994; Rancière, 2010b). The revolution 
must be bottom-up democratic and no longer top-down hierarchical. In this, we can say that Debord was prescient. He foresaw very early in the 1960s that orthodoxy in the critique of ideology would lead the Left to a dead-end. This is the Rimbaud in Guy's politics. It is this crucial insight of Debord which is taken up by Jean-Francois Lyotard and allows him to similarly attack the institution of the university with regard to the latter having any possible role in the passage to action or revolution. Instead, and employing a specific Situationist concept of détourner, Lyotard sees that any genuine revolution must be more authentically thoroughgoing.

Our task will have to be that of displacing [détourner] the entire institution of the university as fully as possible from the functions to which it is restricted by both the ruling class and its own deeply internalised repressions, in order to turn it into a place for working out the means of the critical understanding and expression of reality (Lyotard, 1993, p. 43).

Here, we see Marxism and anarchism combine on the Left to develop a critique of education and the university under the conditions of late capitalism.

These then, in terms of our most urgent theme today, are some of the most paradigmatic examples we can draw from for a vision of a critique of contemporary capitalism. If such a revolution is going to be authentic, if it is avoid the pitfalls of mere ruse and re-commodification, we should take heed of some of the lessons taught by this counter-cultural and heterodox Leftism from the none too distant past of ' 68 and what Kristin Ross has called the "afterlives of '68" (Ross, 2002). Let us resist, then, politically and pedagogically, in the full awareness of our vulnerability and the fragility of the revolutionary "situation".

As the '68ers would have it, No Return to Normal!

\section{References}

Althusser, L. (1994). Ideology and Ideological State Apparatuses (Notes Towards an Investigation). In S. Žižek (Ed.), Mapping Ideology. London: Verso.

Debord, G. (1990). Comments on the Society of the Spectacle. London: Verso.

Debord, G. (2000). Society of the Spectacle. London: Rebel Press.

Freire, P. (1992). Pedagogy of Hope: Reliving Pedagogy of the Oppressed (R. Barr, Trans.). London: Continuum.

Freire, P. (1996). Pedagogy of the Oppressed. London: Continuum.

Gramsci, A. (1986). Prison Notebooks. In J. Donald \& S. Hall (Eds.), Politics and Ideology: A Reader (pp. 100-111). Milton Keynes, UK: Open University Press. 
Irwin, J. (2012). Paulo Freire's Philosophy of Education: Origins, Developments, Impacts and Legacies. London/ New York: Continuum.

Irwin, J. \& Motoh, H. (2014). Žižek and his contemporaries: The emergence of the Slovenian Lacan. London/New York: Bloomsbury.

Lyotard, J. F. (1993). Political Writings (B. Readings \& K. P. Geiman, Trans.). Minnesota: University of Minnesota Press.

Marx, K. (1992a). The Theses on Feuerbach. In K. Marx Early Writings (R. Livingstone \& G. Benton, Trans.). (pp. 421-423). London: Penguin.

Rancière, J. (2010b). Foreword to the English edition. In Althusser's Lesson. London: Continuum.

Ross, K. (2002). May '68 and Its Afterlives. Chicago: University of Chicago Press. https://doi.org/10.7208/chicago/9780226728001.001.0001

Vermès, P. \& Kugelberg, J. (Eds.). (2011). La beauté est dans la rue. Beauty Is In The Street. A Visual Record of the May '68 Paris Uprising. London: Four Corners Books.

Žižek, S. (1989). The Sublime Object of Ideology. London: Verso.

Žižek, S. (1992). Enjoy Your Symptom: Jacques Lacan in Hollywood and Out (First edition). London: Routledge.

Žižek, S. (Ed.). (1994a). Mapping Ideology. London: Verso.

Žižek, S. (1994b). Introduction: The Spectre of Ideology. In Mapping Ideology (pp. 1-33). London: verso.

Žižek, S. (2006). Lacan. London: Grant.

Žižek, S. (2008). Preface: Enjoy your Symptom - or Your Fetish? In S. Žižek (2008) Enjoy Your Symptom: Jacques Lacan in Hollywood and Out (pp. 9-16). London: Routledge. 